\title{
Effect of conjugated linoleic acid and acetate on milk fat synthesis and adipose lipogenesis in lactating dairy cows
}

\author{
N. Urrutia ${ }^{1}$ and K. J. Harvatine ${ }^{2}$ \\ Department of Animal Science, The Pennsylvania State University, University Park 16802
}

\begin{abstract}
During biohydrogenation-induced milk fat depression (MFD), nutrients are spared from milk fat synthesis and are available for other metabolic uses. Acetate is the major carbon source spared and it may increase lipid synthesis in adipose tissue during MFD. The objective of this study was to compare the effect of trans-10,cis-12 conjugated linoleic acid (CLA) and the amount of acetate spared during CLA-induced MFD on adipose tissue lipogenesis. Nine multiparous, lactating, ruminally cannulated Holstein cows $(244 \pm 107 \mathrm{~d}$ in milk; $25 \pm 8.4 \mathrm{~kg}$ of milk/d; mean \pm standard deviation) were randomly assigned to treatments in a $3 \times$ 3 Latin square design. Experimental periods were $4 \mathrm{~d}$ followed by a 10-d washout. Treatments were control $(\mathrm{CON})$, ruminal infusion of acetate $(\mathrm{AC}$; continuous infusion of $7 \mathrm{~mol} / \mathrm{d}$ adjusted to $\mathrm{pH} 6.1$ with sodium hydroxide), or abomasal infusion of CLA (10 g/d of both trans-10,cis-12 CLA and cis-9,trans-11 CLA). Dry matter intake, milk yield, and milk protein yield and percentage were not affected by treatments. Compared with CON, milk fat yield decreased $23 \%$ and fat percent decreased $28 \%$ in CLA, and milk fat yield increased $20 \%$ in AC. Concentration and yield of milk de novo synthesized fatty acids $(<\mathrm{C} 16)$ were reduced and concentration of preformed fatty acids $(>\mathrm{C} 16)$ was increased by CLA, compared with CON. Yield of de novo synthesized fatty acids and palmitic acid was increased by AC, compared with CON. Lipogenesis capacity of adipose tissue explants was decreased $72 \%$ by CLA, but was not affected by AC. Acetate oxidation by adipose explants was not affected by treatments. Treatments had no effect on expression of key lipogenic factors, lipogenic enzymes, and leptin; however, expression of fatty acid binding protein 4 was reduced in CLA compared
\end{abstract}

\footnotetext{
Received November 28, 2016.

Accepted March 16, 2017.

${ }^{1}$ Current address: Instituto de Investigaciones Agropecuarias, INIA Remehue, Osorno, Chile, 5290000.

${ }^{2}$ Corresponding author: kjh182@psu.edu
}

with CON. Additionally, hormone-sensitive lipase and perilipin 1 were decreased by CLA and acetate. Plasma glucose and glucagon concentrations were not affected by treatments; however, CLA increased nonesterified fatty acids $17.7 \%, \beta$-hydroxybutyrate $16.1 \%$, and insulin $27.8 \%$ compared with CON, and AC increased plasma $\beta$-hydroxybutyrate $18 \%$. In conclusion, during CLA-induced MFD in low-producing cow adipose tissue was sensitive to the anti-lipogenic effects of CLA, while spared acetate did not stimulate adipose lipogenesis. However, acetate may play an important role in stimulating lipogenesis and improving energy status in the mammary gland under normal conditions.

Key words: acetate, conjugated linoleic acid, milk fat, spared nutrient

\section{INTRODUCTION}

Biohydrogenation (BH)-induced milk fat depression (MFD) is a condition where milk fat yield is reduced to up to $50 \%$, with no reduction in milk yield or other milk components. Biohydrogenation-induced MFD occurs in response to bioactive fatty acids (FA) formed in the rumen during altered fermentation from feeding highly fermentable or high unsaturated FA diets or diets containing several other risk factors (reviewed by Bauman and Griinari, 2001). Although multiple trans FA formed during altered fermentation reduce milk fat synthesis, trans-10,cis-12 CLA was the first bioactive FA identified and is the most extensively studied. Abomasal infusion of CLA has provided invaluable insights into the mechanism of $\mathrm{BH}$-induced MFD including the downregulation of key lipogenic enzyme [i.e., fatty acid synthase $(F A S N)$ and acetyl-CoA carboxylase $\alpha$ $(A C C \alpha)]$ and lipogenic factors [sterol regulatory element binding protein 1 (SREBP1) and thyroid hormone responsive spot 14 (S14)] in the lactating mammary gland (Harvatine and Bauman, 2006).

During BH-induced MFD, yield of both de novo synthesized and preformed FA are decreased in milk, but a greater reduction occurs in de novo synthesized FA. The main precursor for de novo synthesis of FA in the bovine mammary gland is the 2-carbon VFA acetate. 
Acetate provides the majority of the carbon and approximately half of the reducing equivalents (NADPH) needed for de novo lipogenesis; the remaining NAPDH comes from glucose metabolism through the pentose phosphate pathway (Bauman et al., 1970; Ingle et al., 1973; Smith, 1983). Therefore, the reduction in milk fat synthesis during $\mathrm{BH}$-induced MFD results in a large reduction in mammary utilization of acetate in addition to a decrease in the use of glucose and preformed FA for de novo lipogenesis and triglyceride assembly.

Nutrients spared from milk fat synthesis are expected to reduce intake in the long term. However, a metaanalysis of intake during short-term CLA infusion (3-5 d) observed a small decrease in intake that explained only a portion of the energy spared by the reduction in milk fat (Harvatine et al., 2009b). Therefore, it is possible that during CLA-induced MFD, spared nutrients might be partitioned to other tissues or metabolic uses. In support of this, Harvatine et al. (2009b) observed increased expression of lipogenic enzymes and regulators in adipose tissue after $3 \mathrm{~d}$ of CLA-induced MFD and proposed that the observed response was due to nutrients spared from milk fat synthesis rather than a direct effect of CLA on adipose tissue. In other animal models, including rodents and pigs, it is well known that trans-10, cis-12 CLA directly reduces body fatness (Ostrowska et al., 1999; Park and Pariza, 2007; Foote et al., 2010). In the bovine, CLA decreased lipid synthesis in adipocyte cell culture (Kadegowda et al., 2013) and in adipose tissue explants (Choi et al., 2014). However, most of the work in other animal and culture models use higher doses of CLA than what adipose tissue is exposed to during BH-induced MFD.

The objective of this study was to compare the effect of trans-10,cis-12 CLA and the amount of acetate spared during CLA-induced MFD on adipose tissue lipogenesis. We hypothesized that in the lactating cow, acetate alone would stimulate adipose tissue lipogenesis and therefore explain the contrasting observation that CLA-induced MFD reduced mammary lipogenesis, but increased adipose lipogenesis.

\section{MATERIALS AND METHODS}

\section{Experimental Design and Treatments}

All experimental procedures were approved by the Pennsylvania State University Institutional Animal Care and Use Committee (\#41727). Nine ruminally cannulated multiparous Holstein cows $(244 \pm 107$ DIM; $25 \pm 8.4 \mathrm{~kg}$ of milk/d) were randomly assigned to 1 of 6 treatment sequences in a $3 \times 3$ Latin square design. Three treatment sequences were allocated 2 times each and 3 treatment sequences were allocated once (Supplemental Table S1; https://doi.org/10.3168/jds.201612369). Cows were housed in a tiestall barn located at the Pennsylvania State University Dairy Production Research and Teaching Center. Experimental periods were $4 \mathrm{~d}$ of treatment followed by a 10-d washout. Treatments were control (CON), intraruminal infusion of $7 \mathrm{~mol} / \mathrm{d}$ acetate adjusted to $\mathrm{pH} 6.1$ with sodium hydroxide (AC), and abomasal infusion of $10 \mathrm{~g} / \mathrm{d}$ of trans-10, cis-12 CLA (CLA).

The acetate infusate was prepared by diluting glacial acetic acid in $7 \mathrm{~L}$ of distilled water followed by adjustment to $\mathrm{pH} 6.1$ using sodium hydroxide pellets (J.T. Baker, Center Valley, PA). The control and CLA treatments received a $5.5 \%$ sodium chloride solution, which provided the same moles of sodium and volume of the acetate infusate. Acetate and control infusates were infused $22 \mathrm{~h} / \mathrm{d}$ through the rumen cannula using acid-resistant tubing (Norprene L/S 14, Cole-Parmer, Vernon Hills, IL) and peristaltic pumps (Masterflex L/S drive 7520-35, Cole-Parmer) similar to Sheperd and Combs (1998). Pumps were turned off and lines detached for $1 \mathrm{~h}$ twice per day to allow milking in the parlor $(0500$ and $1700 \mathrm{~h})$. The CLA treatment consisted of abomasal infusion of $34 \mathrm{~g} / \mathrm{d}$ of a CLA methyl ester stock (Lutalin, BASF, Lampertheim, Germany) that contained $30 \%$ trans- 10 , cis- 12 CLA and $30 \%$ cis9,trans-11 CLA to provide $10 \mathrm{~g} / \mathrm{d}$ of trans-10, cis-12 CLA. The CLA stock was infused in equal doses every $6 \mathrm{~h}$ through an abomasal infusion line $[0.5 \mathrm{~cm}$ (i.d.) polyvinyl chloride tubing (Spires et al., 1975)] placed through the rumen cannula. The infusion lines were inserted the day before initiation of treatments and placement in the abomasum was checked daily. The lines were rinsed with $50 \mathrm{~mL}$ of warm water before and after CLA infusion and with $20 \mathrm{~mL}$ of $70 \%$ ethanol after the last water rinse. Control and acetate treatments received $100 \mathrm{~mL}$ of warm water and $20 \mathrm{~mL}$ of $70 \%$ ethanol as a handling control.

\section{Feed Sampling and Analysis}

Cows were fed individually the same TMR once daily $(0800 \mathrm{~h})$ at $110 \%$ of expected intake and intake was recorded daily. Forage and base diet DM concentration was determined weekly for diet adjustment and DMI determination $\left(72 \mathrm{~h}\right.$ in a forced-air oven at $55^{\circ} \mathrm{C}$ ). All individual feed ingredients were sampled by period and composited for analysis of $\mathrm{CP}, \mathrm{NDF}$, and ADF by wet chemistry procedures (Cumberland Valley Analytical Services Inc., Maugansville, MD). Briefly, CP and $\mathrm{ADF}$ was determined according to AOAC International (2000), and NDF according to Van Soest et al. (1991) 
Table 1. Ingredient and nutrient composition of experimental diet ${ }^{1}$

\begin{tabular}{lc}
\hline Variable & $\mathrm{g} / 100 \mathrm{~g}$ of $\mathrm{DM}$ \\
\hline Ingredient & 41.6 \\
Corn silage & 19.0 \\
Alfalfa haylage & 11.8 \\
Canola meal & 7.1 \\
Bakery by-product ${ }^{2}$ & 5.9 \\
Ground corn & 5.3 \\
Cooked soybeans & 4.9 \\
Molasses & 1.4 \\
Cottonseed hulls & 2.8 \\
Mineral-vitamin mix & \\
NPN & \\
Forage & 0.3 \\
Nutrient composition & 60.6 \\
NDF & \\
ADF $^{5}$ & 30.7 \\
CP $^{5}$ & 21.3 \\
Fatty acids $^{6}$ & 16.9 \\
Starch & 4.2 \\
\hline
\end{tabular}

${ }^{1}$ Cows were fed the same diet during experimental periods.

${ }^{2}$ Contained (g/100 g of DM): $17 \%$ CP, $28.2 \%$ ADF, $39.1 \%$ NDF, $11 \%$ fatty acids, and $20 \%$ starch.

${ }^{3}$ Contained (\%, as-fed basis): 45.8 dried corn distillers grains with solubles, 35.8 limestone $(38 \% \mathrm{Ca}), 8.3$ magnesium oxide $(54 \% \mathrm{Mg})$, 6.4 salt, 1.73 vitamin ADE premix, 1.09 selenium premix (0.06\% selenium), and 0.88 trace mineral mix. Composition (DM basis): $11 \% \mathrm{CP}$ $40 \% \mathrm{NDF}, 6.9 \%$ ADF, $14.9 \% \mathrm{Ca}, 0.35 \% \mathrm{P}, 4.58 \% \mathrm{Mg}, 0.41 \% \mathrm{~K}, 0.31 \%$ $\mathrm{S}, 357 \mathrm{mg} / \mathrm{kg}$ of Cu, $1,085 \mathrm{mg} / \mathrm{kg}$ of Zn, $181 \mathrm{mg} / \mathrm{kg}$ of Fe, $6.67 \mathrm{mg} / \mathrm{kg}$ of Se, $125,875 \mathrm{IU} / \mathrm{kg}$ of vitamin A (retinyl acetate), 31,418 IU $/ \mathrm{kg}$ of vitamin D (activated 7-dehydrocholesterol), and $946 \mathrm{IU} / \mathrm{kg}$ of vitamin E (DL- $\alpha$ tocopheryl acetate).

${ }^{4}$ Nonprotein nitrogen fed as a slow-release urea (Optigen, Alltech Inc., Lexington, KY; $259 \%$ CP, DM basis).

${ }^{5}$ Analyzed by Cumberland Valley Analytical Services (Maugansville, MD).

${ }^{6}$ Total fatty acid content was determined using 2 internal standards and quantified by GC-flame ionization detector.

using heat-stable amylase and sodium sulfite. Starch was determined by an enzymatic method (Karkalas, 1985) using Hazyme enzyme (Centerchem, Norwalk, $\mathrm{CT}$ ), after samples were gelatinized with sodium hydroxide. Ingredient and nutrient composition of the diet is reported in Table 1. Fatty acid composition of feed ingredients was determined as described by Rico and Harvatine (2013) and diet fatty acid concentration is reported in Supplemental Table S2 (https://doi. org/10.3168/jds.2016-12369).

\section{Milk Sampling and Analysis}

Cows were milked twice daily at 0500 and $1700 \mathrm{~h}$ and milk yield was determined by an integrated milk meter (AfiMilk; SAE Afikim, Israel). The parlor was calibrated using a stall deviation calculated using data from the entire herd ( $>200$ cows) over $7 \mathrm{~d}$. Stall deviations were determined by modeling the effect of day, milking (AM/PM), cow, and stall, excluding observa- tions of experimental cows during treatment periods. Milk was sampled at both milkings on d 3 and 4 of each treatment period. One milk subsample was stored at $4^{\circ} \mathrm{C}$ with preservative (Bronolab-WII; D\&F Control Systems Inc., Dublin, CA) until analyzed for fat (filter B) and protein by infrared spectroscopy [Fossomatic 4000 Milko-Scan and 400 Fossomatic, Foss Electric; AOAC International (2000) method 972.160, Dairy One DHIA]. Fat cakes were obtained from a second subsample by centrifugation at $1,300 \times g$ for 20 min at $4^{\circ} \mathrm{C}$ before freezing. Fatty acid profile was determined as described by Rico and Harvatine (2013) with slight modifications. Briefly, milk lipids were extracted with hexane:isopropanol, transmethylated in the presence of sodium methoxide, and FAME quantified by gas chromatography with a flame ionization detector and a capillary column [SP-2560; $100 \mathrm{~m} \times 0.25 \mathrm{~mm}$ (i.d.) with $0.2-\mu \mathrm{m}$ film thickness; Supelco Inc., Bellefonte, $\mathrm{PA}$ ]. Initial oven temperature was $80^{\circ} \mathrm{C}$ and the oven temperature increased $2^{\circ} \mathrm{C} / \mathrm{min}$ to $190^{\circ} \mathrm{C}$ for $15 \mathrm{~min}$ and then increased $5^{\circ} \mathrm{C} / \mathrm{min}$ to $215^{\circ} \mathrm{C}$ for $3 \mathrm{~min}$. Inlet and detector temperatures were $250^{\circ} \mathrm{C}$ with a $50: 1$ split ratio. Peaks were identified using FAME standards (GLC 68D and 780 and pure trans-10,cis-12 CLA and cis-9,trans-11 CLA, Nu-Chek Prep Inc., Elysian, MN; Bacterial Acid Methyl Ester Mix, 47080-U, SigmaAldrich Inc., St. Louis, MO; and GLC 110 mixture, Matreya LLC., State College, PA) and recoveries of individual FA were determined using an equal weight reference standard (GLC 461; Nu-Chek Prep Inc.).

\section{Adipose Tissue Biopsies}

Adipose tissue biopsies were collected 5 to $6 \mathrm{~h}$ after the morning milking at the end of each treatment period. The biopsy was taken from the tail-head region as described in Harvatine et al. (2009b), and sides were alternated between periods. Briefly, cows were sedated with xylazine (i.v., $0.5-1 \mathrm{mg} / 45 \mathrm{~kg}$ of BW) and provided local subcutaneous anesthesia $(15 \mathrm{~mL}$, lidocaine hydrochloride $2 \%$ ) administered in a circular pattern around the incision site. Once the anesthesia was effective, an incision was made in the skin and adipose tissue was dissected. The adipose tissue sample (1 to $1.5 \mathrm{~g}$ ) was rinsed in sterile $0.9 \%$ saline. Two subsamples were snap-frozen in liquid nitrogen and subsequently stored at $-80^{\circ} \mathrm{C}$ until RNA extraction, and a third subsample $(\sim 0.5 \mathrm{~g})$ was immediately placed in saline transport buffer $\left(0.9 \% \mathrm{NaCl}, 25 \mathrm{~m} M\right.$ HEPES, $\left.\mathrm{pH} 7.4,37^{\circ} \mathrm{C}\right)$ for immediate use in the lipogenesis assay described below. The incision was irrigated and closed with polyglactin 910 suture (Ethicon Vicryl 0, Johnson \& Johnson, New Brunswick, NJ) using simple interrupted stitches. 


\section{Adipose Tissue Explant}

A portion of the adipose tissue was used within 30 min to determine acetate incorporation into fatty acids and oxidation to $\mathrm{CO}_{2}$ as previously described (Bauman et al., 1973; Ingle et al., 1973). Briefly, tissue explants were sliced using a Stadie-Riggs hand microtome, weighed and incubated in triplicates (approximately $100 \mathrm{mg}$ ) in flasks containing $3 \mathrm{~mL}$ of freshly prepared (daily) Krebs-Ringer bicarbonate buffer ( $\mathrm{pH}$ 7.4) plus $20 \mathrm{~m} M$ HEPES, $10 \mathrm{~m} M$ acetate, $5 \mathrm{~m} M$ glucose, $2 \mu \mathrm{g} / \mathrm{mL}$ of insulin, and $1-{ }^{14} \mathrm{C}$ acetate $(0.33 \mu \mathrm{Ci} / \mathrm{mL}$; American Radiolabeled Chemicals Inc., St. Louis, MO). Flasks were gassed $\left(\mathrm{O}_{2}\right.$ and $\left.\mathrm{CO}_{2}, 95: 5\right)$ and sealed with rubber caps equipped with a plastic bucket containing a $2 \times 2$ $\mathrm{cm}$ piece of filter paper for capture and measurement of ${ }^{14} \mathrm{CO}_{2}$. Incubation was performed in a shaking water bath at $37^{\circ} \mathrm{C}$ for $3 \mathrm{~h}$, terminated with addition of 250 $\mu \mathrm{L}$ of $0.5 \mathrm{M}$ sulfuric acid, and $\mathrm{CO}_{2}$ was trapped by addition of $100 \mu \mathrm{L}$ of $25 \%$ potassium hydroxide to filter paper in the plastic buckets. Lipids were extracted in petroleum ether, and radioactivity of lipids and filter paper were quantified as described by Bauman et al. (1970).

\section{Gene Expression Analysis}

Total RNA was isolated from approximately $250 \mathrm{mg}$ of adipose tissue using the E.Z.N.A. Total RNA Kit II with on-column DNase treatment (Omega Bio-Tek, Norcross, GA). The RNA concentration and integrity were determined by an Experion Automated Electrophoresis Station (Bio-Rad, Hercules, CA). Total RNA was reverse transcribed using the High Capacity cDNA Reverse Transcription Kit (Applied Biosystems, Foster City, CA) with random primers. Real-time quantitative RT-PCR reactions were conducted using PerfeCTa SYBR Green SuperMix, ROX (Quanta Biosciences, Gaithersburg, MD) in an Applied Biosystems 7900HT Fast Real-Time PCR System (Applied Biosystems) and $400 \mathrm{n} M$ of gene specific forward and reverse primers as shown in Supplemental Table S3 (https://doi. org/10.3168/jds.2016-12369; Invitrogen, Carlsbad, CA). Each reaction was performed in triplicate wells, and sample message level was determined relative to a dilution curve of pooled cDNA (Prism, 2001) and analyzed relative to the geometric mean of 2 housekeeping genes [ribosomal protein 9 (RPS9) and $\beta 2$ microglobulin (B2M)].

\section{Blood Sampling and Analysis}

Blood samples were collected from the tail vein using potassium EDTA vacuum tubes (Greiner Bio-One
North America Inc., Monroe, NC) 6 times over d 3 and 4 of each period to represent every $4 \mathrm{~h}$ of a day (0000, 0400, 0800, 1200, 1600, and 2000 h). Blood was immediately placed on ice, centrifuged within $30 \mathrm{~min}$ at $1,300 \times g$ for $15 \mathrm{~min}$ at $4^{\circ} \mathrm{C}$, and plasma was harvested and stored at $-20^{\circ} \mathrm{C}$ until laboratory analysis. Prior to analysis, plasma samples were composited by cow within period. Composited plasma samples were analyzed for insulin (Mercodia Bovine Insulin ELISA, Mercodia AB, Uppsala, Sweden), glucose (PGO Enzyme procedure no. P 7119; Sigma-Aldrich; Raabo and Terkildsen, 1960), glucagon [RIA kit catalog no. GL-32K, EMD Millipore Corporation, Billerica, MA, as in Bradford and Allen (2005)], nonesterified fatty acids [NEFA; Wako HR Series NEFA-HR kit, Wako Chemicals USA, Richmond, VA, as modified by Ballou et al. (2009)], BHB (procedure \#2440, Stanbio Laboratory, Boerne, TX), total phospholipids (Phospholipids C, Wako Chemicals USA), triglycerides (L-Type TG M, Wako Chemicals USA), and free cholesterol (Free Cholesterol E, Wako Chemicals USA).

Total plasma FA profile was also determined by extraction of $1 \mathrm{~mL}$ of plasma with hexane:isopropanol with methyl tridecenoate and nonadecanoate acid as internal standards (Nu-Chek Prep Inc.). Fatty acids were directly methylated in a dual methylation procedure using $0.5 \mathrm{M}$ sodium methoxide in methanol at $50^{\circ} \mathrm{C}$ for $10 \mathrm{~min}$ and $5 \%$ methanolic $\mathrm{HCl}$ at $80^{\circ} \mathrm{C}$ for $10 \mathrm{~min}$ (Kramer et al., 1997). Fatty acid methyl esters were quantified as described above with a modified temperature program (initial $70^{\circ} \mathrm{C}$, increased $8^{\circ} \mathrm{C} / \mathrm{min}$ to $110^{\circ} \mathrm{C}$, increased $5^{\circ} \mathrm{C} / \mathrm{min}$ to $170^{\circ} \mathrm{C}$ for $10 \mathrm{~min}$, increased $4^{\circ} \mathrm{C} /$ min to $215^{\circ} \mathrm{C}$, and held for $25 \mathrm{~min}$ ).

\section{Statistical Analysis}

Data were analyzed using REML and the fit model procedure of JMP (version Pro 10.0.2, SAS Institute Inc., Cary, NC). The model included the random effect of cow nested within sequence, sequence, and period and the fixed effect of treatment.

Gene expression data were analyzed relative to the geometric mean of B2M and RPS9 and the model included tissue replicate as a random effect (subsamples analyzed independently). Data were log-transformed for analysis and back-transformed data are reported. Data points with studentized residuals outside of \pm 2.5 for tissue incubation and gene expression variables and \pm 3.5 for performance variables were considered outliers and excluded from analysis. A protected LSD separation was conducted to compare treatment means when treatment was significant. Differences were declared significant at $P \leq 0.05$ and tendencies at $P \leq 0.10$. 
URRUTIAAND HARVATINE

Table 2. Effect of CLA and acetate on DMI, milk yield, and composition

\begin{tabular}{|c|c|c|c|c|c|}
\hline \multirow[b]{2}{*}{ Variable } & \multicolumn{3}{|c|}{ Treatment $^{1}$} & \multirow[b]{2}{*}{$\mathrm{SE}$} & \multirow[b]{2}{*}{$P$-value ${ }^{2}$} \\
\hline & $\mathrm{CON}$ & CLA & Acetate & & \\
\hline DMI, $\mathrm{kg} / \mathrm{d}$ & 25.6 & 24.8 & 26.4 & 1.19 & 0.20 \\
\hline Milk yield, $\mathrm{kg} / \mathrm{d}$ & 22.9 & 23.5 & 25.4 & 3.53 & 0.22 \\
\hline \multicolumn{6}{|l|}{ Milk fat } \\
\hline$\%$ & $3.87^{\mathrm{a}}$ & $2.77^{\mathrm{b}}$ & $4.10^{\mathrm{a}}$ & 0.20 & $<0.001$ \\
\hline $\mathrm{g} / \mathrm{d}$ & $864^{\mathrm{b}}$ & $669^{c}$ & $1,041^{\mathrm{a}}$ & 138 & $<0.01$ \\
\hline \multicolumn{6}{|l|}{ Milk protein } \\
\hline$\%$ & 3.47 & 3.47 & 3.47 & 0.11 & 1.00 \\
\hline $\mathrm{g} / \mathrm{d}$ & 783 & 830 & 888 & 127 & 0.21 \\
\hline \multicolumn{6}{|l|}{ Milk lactose } \\
\hline$\%$ & 4.36 & 4.39 & 4.38 & 0.2 & 0.98 \\
\hline \multirow{2}{*}{\multicolumn{6}{|c|}{ Milk FA source, ${ }^{3} \mathrm{~g} / \mathrm{d}$}} \\
\hline & & & & & \\
\hline$<16 \mathrm{C}$ & $200^{\mathrm{b}}$ & $137^{\mathrm{c}}$ & $244^{\mathrm{a}}$ & 30.1 & $<0.001$ \\
\hline $16 \mathrm{C}$ & $223^{\mathrm{b}}$ & $162^{\mathrm{c}}$ & $278^{\mathrm{a}}$ & 36.3 & $<0.001$ \\
\hline$>16 \mathrm{C}$ & $334^{\mathrm{ab}}$ & $288^{\mathrm{b}}$ & $394^{\mathrm{a}}$ & 44.7 & $<0.05$ \\
\hline
\end{tabular}

${ }^{\mathrm{a}-\mathrm{C}}$ Least squares means within a row that do not share a superscript are significantly different $(P<0.05)$.

${ }^{1}$ Treatments were control (CON), 4-d abomasal infusion of $10 \mathrm{~g} / \mathrm{d}$ of trans-10, cis-12 CLA and cis-9, trans-11 CLA (CLA), and 4-d rumen infusion of $7 \mathrm{~mol} / \mathrm{d}$ of acetate adjusted to $\mathrm{pH} 6.1$ with sodium hydroxide (acetate); $\mathrm{n}=9$ per treatment.

${ }^{2}$ Effect of treatment.

${ }^{3}$ Calculated from milk fat yield and milk fatty acid (FA) composition. FA $<16 \mathrm{C}$ originate from de novo synthesis, FA $>16 \mathrm{C}$ originate from plasma and $16 \mathrm{C}$ FA originate from both sources. Odd and branched FA were excluded.

\section{RESULTS AND DISCUSSION}

Treatments were designed to induce MFD with trans-10,cis-12 CLA to observe the effect of both CLA and nutrients spared from milk fat synthesis and to provide a similar amount of acetate to that spared during MFD to test the direct effect of spared acetate on adipose lipogenesis independent of trans-10,cis-12 CLA. The acetate treatment provided $7 \mathrm{~mol} / \mathrm{d}$ of acetate $(424 \mathrm{~g})$, which was the calculated acetate spared during a $45 \%$ reduction in milk fat synthesis expected with $10 \mathrm{~g} / \mathrm{d}$ of trans-10,cis-12 CLA (de Veth et al., 2004 ) for an average cow (36 kg of milk/d; $3.5 \%$ milk fat) based on the stoichiometry of de novo lipogenesis (Baldwin, 1995). Trans-10, cis-12 CLA-induced MFD also results in a sparing of glucose (NADPH synthesis through the pentose phosphate pathway and glycerol for triglyceride synthesis) and preformed FA, but these were not included because of the difficulty of infusing without confounding effects. Briefly, exogenous glucose would change liver gluconeogenesis (Bartley and Black, 1966; Lemosquet et al., 2004) and reduced glucose demand would spare propionate in the liver because of homeostatic regulation. Abomasal infusion of glucose would also be expected to increase glucagon-like peptide 1 among other signaling hormones (Lemosquet et al., 2004) and would be extensively metabolized by the gut. Abomasal infusion of preformed FA would also be expected to modify gut peptides (Litherland et al., 2005) and intravenous infusion is difficult without induction of a stress response. Because acetate is a main substrate for adipose tissue lipogenesis (Ingle et al., 1973), we chose to test spared acetate in isolation in the current experiment.

\section{Milk Production and Fatty Acid Profile}

Dry matter intake was not affected by treatments (Table 2). The wide range of DIM $(244 \pm 107$; mean $\pm \mathrm{SD})$ and production level $(23.9 \pm 8.6 \mathrm{~kg} / \mathrm{d}$; mean \pm SD), and thus energy balance and physiological state of the cows used may have limited our ability to observe the small decrease in DMI during CLA-induced MFD as previously reported by Harvatine et al. (2009b).

Milk yield and milk protein and lactose yield and concentration were not affected by treatments (Table 2). During BH-induced MFD spared acetate may be partitioned toward milk synthesis. However, Harvatine et al. (2009b) reported no increase in milk yield in a meta-analysis of short-term abomasal CLA infusion studies, although others have reported increased milk yield with dietary CLA supplements (de Veth et al., 2006; Odens et al., 2007). A production response may depend on lactation number, lactation stage (physiological state, energy balance), production level, and 
extent of MFD. For example, in early-lactation or highproducing cows that are in negative energy balance, spared acetate is more likely to be used by the mammary gland for lactose and protein synthesis (de Veth et al., 2006), and hence, increase milk yield to a higher level. However, if the cow has reached maximal potential milk yield, spared acetate could be partitioned to other tissues such as adipose to improve energy balance and feedback mechanisms will reduce energy intake (Harvatine et al., 2009b). Following the same logic, during acetate infusion in a non-milk-fat-depressed cow, acetate may be used for milk and milk fat synthesis, resulting in little partitioning to adipose tissue. In the current study, acetate infusions numerically increased milk yield by $11.3 \%$ over the infusion period compared with control.

Trans-10,cis-12 CLA decreased milk fat yield and concentration 23 and $28 \%$, respectively, compared with CON (both $P<0.05$ ). The reduction in milk fat yield was less than expected for the dose of trans-10, cis-12 CLA [45.2\% expected reduction (de Veth et al., 2004)], and transfer of trans-10,cis-12 CLA to milk in the current experiment was only $15.3 \%$, slightly lower than the $22 \%$ reported in a meta-regression analysis of 7 trans-10,cis-12 CLA abomasal infusion experiments $\left(22 \%, \mathrm{R}^{2}=0.94\right.$; de Veth et al., 2004). However, the reduction in milk fat yield was also less than expected for the concentration $(0.25 \mathrm{~g} / 100 \mathrm{~g}$ of FA) and yield (1.53 $\mathrm{g} / \mathrm{d}$ ) of trans-10,cis-12 CLA in milk [39.6 and $42.4 \%$ expected reduction, respectively; de Veth et al. (2004)], suggesting that the set of cows used in this experiment (low-producing cows) were slightly less responsive to the inhibitory effects of trans-10,cis-12 CLA. Because milk fat yield was not reduced to the extent expected, the acetate infusion provided more acetate than spared for the degree of MFD achieved in the CLA treatment ( 5 vs. $7 \mathrm{~mol} / \mathrm{d}$ ).

Milk fat yield unexpectedly increased $177 \mathrm{~g} / \mathrm{d}(20 \%$ increase) in $\mathrm{AC}$ compared with $\mathrm{CON}(P<0.05)$. This demonstrates that milk fat synthesis is responsive to short-term variations in acetate supply during conditions of normal rumen fermentation (no apparent $\mathrm{BH}$ induced MFD). A recent meta-analysis reported that ruminal infusion of acetate linearly increased milk fat yield and concentration (Maxin et al., 2011b); however, this analysis was based on papers with limited replication published over $30 \mathrm{yr}$ ago (1955-1978) with lower producing cows (approximately $14.3 \pm 3.2 \mathrm{~kg} / \mathrm{d}$ ) fed diets different from contemporary TMR. In a more recent study, Sheperd and Combs (1998) ruminally infused 36 $\mathrm{mol} / \mathrm{d}$ of acetate $(2.16 \mathrm{~kg})$ for $21 \mathrm{~d}$ and observed a $24 \%$ increase in milk fat yield $(280 \mathrm{~g})$ and a $20 \%$ increase in milk fat concentration (3.41 vs. 4.08\%). However,
Maxin et al. (2011a) did not observe increased milk fat yield when ruminally infusing 1,500 $\mathrm{g} / \mathrm{d}$ of acetate, because of a decrease in DMI and milk yield.

Importantly, the milk fat response to acetate infusion was not alleviating BH-induced MFD as control cows in the current experiment were well above expected milk fat for Holstein cows (3.87\% in current experiment) and had low levels of alternate biohydrogenation intermediates in milk fat as described below (Supplemental Tables S4 and S5; https://doi.org/10.3168/jds.201612369).

Yield of de novo synthetized FA $(<16 \mathrm{C})$ and FA of mixed origin (16 C) decreased in CLA compared with CON (Table 2 and Supplemental Tables S4 and S5; https://doi.org/10.3168/jds.2016-12369). The pattern and magnitude of changes in milk FA in response to CLA was similar to that expected based on previous research (e.g., Baumgard et al., 2001; Donnelly et al., 2009). Acetate infusion increased de novo and 16C FA yield 43.6 and $55.0 \mathrm{~g} / \mathrm{d}$, respectively, and numerically increased preformed FA $59.5 \mathrm{~g} / \mathrm{d}$. Although yield of all de novo synthetized FA was higher in AC, myristic acid increased the most $(+21 \mathrm{~g} / \mathrm{d}$; Supplemental Table S5; https://doi.org/10.3168/jds.2016-12369). Increases in de novo and 16C FA have been reported during acetate infusion (Storry and Rook, 1965a,b).

Concentration and yield of trans-10 C18:1 and trans10,cis-12 CLA were not different in AC compared with $\mathrm{CON}$, and their low levels indicated normal rumen biohydrogenation capacity and pathways.

\section{Plasma CLA and Select Hormones and Metabolites}

Plasma concentration of cis-9,trans-11 CLA increased from 0.10 to $0.21 \%$ and trans-10, cis- 12 CLA increased from 0.01 to $0.10 \%$ of identified FA in CLA compared with CON (Table 3). This is comparable to the increase observed in Harvatine and Bauman (2011), where trans-10,cis-12 CLA reached $0.17 \pm 0.01 \%$ of plasma FA with a dose of $15 \mathrm{~g} / \mathrm{d}$. Treatments did not greatly affect other plasma FA (Supplemental Table S7; https://doi.org/10.3168/jds.2016-12369).

Plasma glucose and glucagon concentration were not affected by treatments; however, CLA increased NEFA $17.7 \%$, BHB $16.1 \%$, and insulin $27.8 \%$ compared with CON (all $P<0.05$; Table 3). Previously, long-term supplementation of CLA in early lactation (Pappritz et al., 2011) and short and long-term supplementation in established lactation (Baumgard et al., 2002a; Perfield et al., 2002) did not cause changes in plasma NEFA and BHB. However, other studies have reported increased BHB after 9 wk of supplementation with no change in NEFA (Bernal-Santos et al., 2003), decreased NEFA af- 
ter $40 \mathrm{~d}$ of CLA supplementation postpartum (Odens et al., 2007), and increased NEFA during short-term infusion of trans-10, cis-12 CLA in postpeak lactation cows (Baumgard et al., 2000). In pigs, CLA increased plasma NEFA and reduced plasma triglycerides, but had no effect on insulin (12.5 g/d of a mixture of cis-9,trans-11 and trans-10,cis-12 CLA; Ostrowska et al., 2002), suggesting that CLA decreased body fat accretion by increasing lipolysis and reducing lipogenesis from preformed FA. In the current experiment, increased BHB in the CLA treatment could be attributed to spared butyrate from milk fat synthesis during CLA-induced MFD.

Baumgard et al. (2002b) reported no effect of trans-10,cis-12 CLA on plasma insulin during shortterm infusion using a small number of animals ( $\mathrm{n}=$ 3), whereas Saremi et al. (2014) observed increased plasma insulin during long-term supplementation of CLA in dairy cows. In the current experiment, CLA increased plasma insulin. Conjugated linoleic acid and medium- and long-chain FA have been shown to potentiate insulin secretion in in vivo (mouse) and in vitro (rat and mouse) models through activation of $\mathrm{G}$ protein-coupled receptor 40 (GPR-40), which is highly expressed in pancreatic $\beta$ cells (Itoh et al., 2003; Covington et al., 2006; Schmidt et al., 2011). Although this mechanism has not been studied in the cow, the insulin response observed in the current study might be linked to a similar GPR40 mechanism, either in response to CLA or to other circulating long-chain FA, as CLA increased plasma NEFA in the current experiment $(17.7 \%$ increase in NEFA, $P<0.05$; Table 3 ). The mechanism was outside of the scope of the current experiment.
Insulin is a homeostatic regulator of lipid metabolism in bovine adipose tissue as it stimulates lipogenesis through preventing the phosphorylation of $\mathrm{ACC} \alpha$ and inhibits lipolysis by suppressing the activation of hormone-sensitive lipase (Bauman and Currie, 1980). Despite increased concentration of insulin with CLA, lipolysis did not appear to be inhibited as plasma NEFA was increased (Table 3). This may be indicative of insulin resistance; however, measurement of insulin sensitivity (hyperinsulinemic-euglycemic clamp) was out of the scope of this experiment. High doses of CLA caused insulin resistance in rodent models (Park and Pariza, 2007), presumably due to stimulation of adipose inflammation that occurs at very high doses of CLA (Foote et al., 2010). The dose of CLA required for induction of MFD and the dose used in the current experiment are very low compared with rodent models and previous work has shown no change in response to glucose and epinephrine challenge (Baumgard et al., 2002a).

Acetate infusion had no effect on plasma glucose, NEFA, or glucagon concentration, but increased plasma BHB concentration compared with $\mathrm{CON}(P<$ $0.05)$. Approximately $50 \%$ of rumen butyrate originates from acetate (Sutton et al., 2003), and when absorbed is converted to BHB in the rumen wall. Rumen epithelial cells synthesize BHB from acetate (Leighton et al., 1983), whereas little or no conversion of plasma acetate to BHB is expected (Storry and Rook, 1965b). Importantly, increased BHB during acetate infusion has been reported previously (Storry and Rook, 1965a; Sheperd and Combs, 1998) and has been proposed as a mechanism for increasing milk fat yield with ruminal acetate infusions.

Table 3. Effect of CLA and acetate on plasma concentration of key metabolic hormones, metabolites, and CLA isomers

\begin{tabular}{|c|c|c|c|c|c|}
\hline \multirow[b]{2}{*}{ Item } & \multicolumn{3}{|c|}{ Treatment $^{1}$} & \multirow[b]{2}{*}{$\mathrm{SE}$} & \multirow[b]{2}{*}{$P$-value ${ }^{2}$} \\
\hline & $\mathrm{CON}$ & CLA & Acetate & & \\
\hline Glucose, $\mathrm{mg} / \mathrm{dL}$ & 56.2 & 57.7 & 57.0 & 2.2 & 0.28 \\
\hline $\mathrm{NEFA}^{3}, \mu \mathrm{Eq} / \mathrm{L}$ & $134^{\mathrm{b}}$ & $158^{\mathrm{a}}$ & $138^{\mathrm{b}}$ & 12.4 & 0.04 \\
\hline $\mathrm{BHB}, \mu M$ & $682^{\mathrm{b}}$ & $792^{\mathrm{a}}$ & $804^{\mathrm{a}}$ & 56.0 & 0.02 \\
\hline Glucagon, pg/mL & 281 & 267 & 270 & 26.9 & 0.28 \\
\hline Insulin, $\mu \mathrm{g} / \mathrm{dL}$ & $113^{\mathrm{b}}$ & $145^{\mathrm{a}}$ & $106^{\mathrm{b}}$ & 20.1 & 0.03 \\
\hline $\begin{array}{l}\text { Plasma CLA, } \% \text { of FA } \\
\text { cis- } 9, \text { trans- } 11 \\
\text { trans- } 10, \text { cis- } 12\end{array}$ & $0.10^{\mathrm{b}}$ & $\begin{array}{l}0.21^{\mathrm{a}} \\
0.10^{\mathrm{a}}\end{array}$ & $\begin{array}{l}0.10^{\mathrm{b}} \\
0.02^{\mathrm{b}}\end{array}$ & $\begin{array}{l}0.01 \\
0.01\end{array}$ & $\begin{array}{l}<0.001 \\
<0.001\end{array}$ \\
\hline \multicolumn{6}{|c|}{$\overline{\mathrm{a}, \mathrm{b}}$ Least squares means within a row that do not share a superscript are significantly different $(P<0.05)$. } \\
\hline \multicolumn{6}{|c|}{$\begin{array}{l}{ }^{1} \text { Treatments were control }(\mathrm{CON}), 4-\mathrm{d} \text { abomasal infusion of } 10 \mathrm{~g} / \mathrm{d} \text { of trans-10, } \text {,is- } 12 \text { CLA and cis-9, trans- } \\
\text { CLA (CLA), and } 4 \text {-d rumen infusion of } 7 \mathrm{~mol} / \mathrm{d} \text { of acetate adjusted to } \mathrm{pH} 6.1 \text { with sodium hydroxide (acetat } \\
\mathrm{n}=9 \text { per treatment. }\end{array}$} \\
\hline
\end{tabular}


Characterization of the effect of CLA and acetate infusions on plasma lipid fractions has been limited. No effect of CLA or acetate was observed on the concentration of total plasma triglycerides, phospholipids, and free cholesterol (Supplemental Table S6; https:// doi.org/10.3168/jds.2016-12369). Variable responses have been reported in other animal models, including a cholesterol and triglyceride lowering-effect of CLA and acetate in some animal models (Terpstra, 2004; Fushimi et al., 2006; Kondo et al., 2009).

\section{Adipose Tissue Lipogenesis}

Lipogenic capacity of adipose tissue was measured using an explant system that quantifies incorporation of labeled acetate into lipids and $\mathrm{CO}_{2}$ (Ingle et al., 1973). We expected that lipogenic capacity would be increased in CLA and with acetate infusion because previous work has shown increased expression of lipogenic genes in adipose tissue of CLA-MFD cows presumably due to spared nutrients from milk fat synthesis (Harvatine et al., 2009b); however, lipogenesis capacity was decreased $72 \%$ by CLA and was not affected by acetate (Figure 1) indicating that trans-10,cis-12 CLA can be anti-lipogenic in adipose tissue of lactating cows. In previous work, CLA reduced lipogenesis in lactating mammary tissue explants by $82 \%$ in the cow (Baumgard et al., 2002b) and $40 \%$ in the mouse (Harvatine et al., 2014). Conjugated linoleic acid also reduced lipogenic capacity $40 \%$ in adipose explants treated ex vivo with CLA (Choi et al., 2014); however, this technique has limitations due to prolonged exposure to treatments that may also trigger inflammation and natural tissue metabolic processes that occur ex vivo.

Because acetate is the major carbon precursor for lipid synthesis in the ruminant (Bauman et al., 1970, 1973), we expected that acetate would stimulate lipogenesis in adipose tissue explants, but this did not occur. Some possible reasons include that the acetate spared in CLA and exogenous acetate from acetate infusion could have been partitioned to other tissues and metabolic uses, such as protein and lactose synthesis in the mammary gland, muscle, liver, and fetus, rather than to adipose (Bauman and Currie, 1980; Bell and Bauman, 1994). Additionally, during CLA-induced MFD, nutrients other than acetate that are also spared from milk fat synthesis (glucose, preformed fatty acids) might be important in mediating a lipogenic response on adipose tissue (e.g., though insulin). In other animal models, short-chain FA, including acetate, have shown to inhibit lipolysis and lipogenesis in liver and adipose tissue and the response is proposed to be mediated through the short chain FA G-protein-coupled
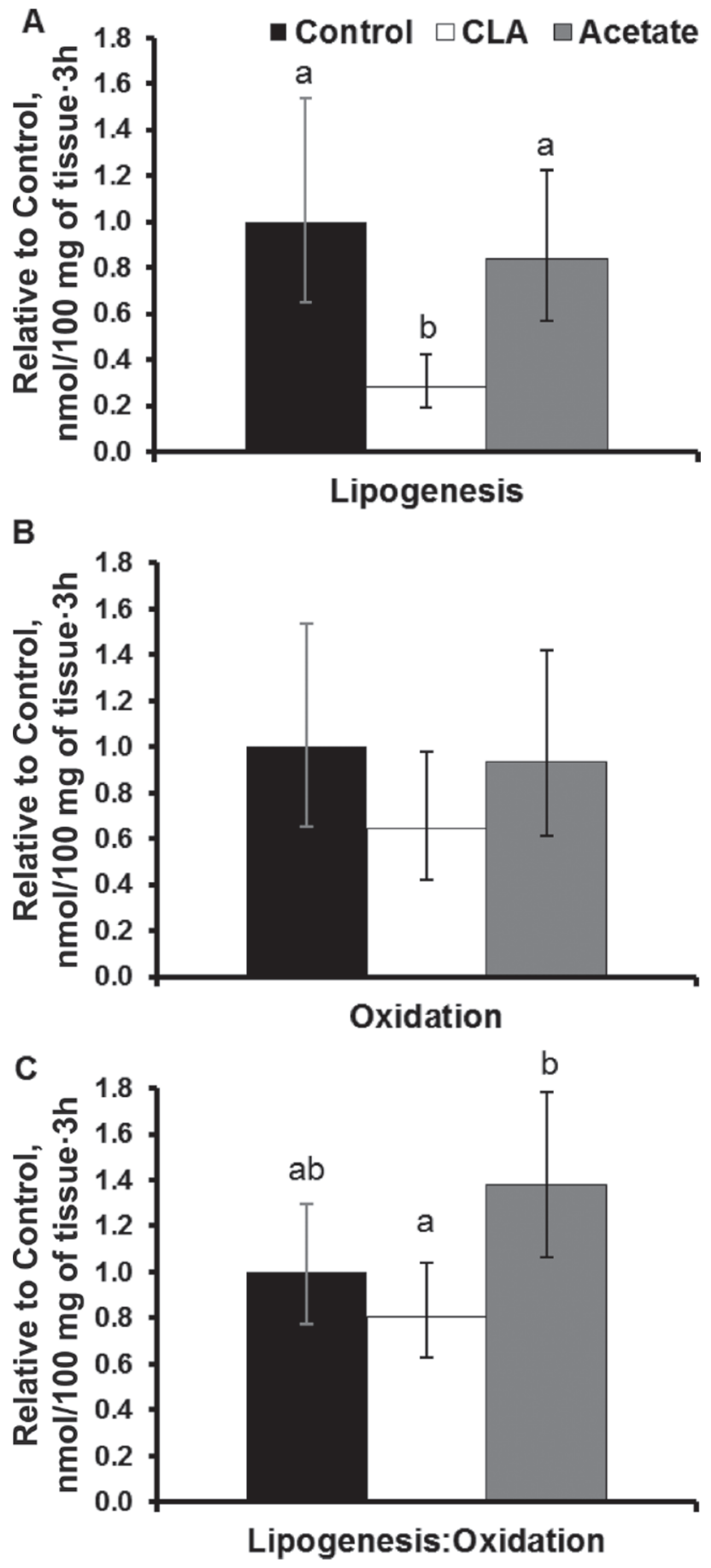

Figure 1. Effect of CLA and acetate on rates of lipogenesis, oxidation, and lipogenesis to oxidation ratio by explants of adipose tissue. Treatments were control, 4-d abomasal infusion of $10 \mathrm{~g} / \mathrm{d}$ of trans10,cis-12 CLA and cis-9,trans-11 CLA (CLA), and 4-d rumen infusion of $7 \mathrm{~mol} / \mathrm{d}$ of acetate adjusted to $\mathrm{pH} 6.1$ with sodium hydroxide (acetate) $\mathrm{n}=9$ per treatment. Lipogenic capacity and oxidation rates of adipose tissue was measured using an explant system that quantifies incorporation of labeled acetate into lipids and $\mathrm{CO}_{2}$. Values are $\mathrm{LSM} \pm \mathrm{SE}$ of logarithmic back-transformed data expressed relative to control. Means that do not share a letter $(\mathrm{a}, \mathrm{b})$ are significantly different $(P<0.05)$. 
receptors (GPR41 and GPR43). However, den Besten et al. (2015) demonstrated a peroxisome proliferatoractivated receptor $\gamma(\mathrm{PPAR} \gamma)$-dependent mechanism for short-chain FA, including acetate to prevent weight gain, reduce lipogenesis capacity from acetate, increase energy expenditure, and FA oxidation in mice fed a high-fat diet. These studies were conducted in mice and cell culture models, and it is unknown if adipose tissue in lactating ruminants would respond differently to short-chain FA. Additionally, the effect that acetate may have on hormonal regulation of metabolism and nutrient partitioning in the cow is unclear, although no differences in concentration of key plasma metabolites and hormones were observed in the current study.

Acetate oxidation to $\mathrm{CO}_{2}$ was not affected by treatments; however, Baumgard et al. (2002b) observed a $61 \%$ reduction in acetate oxidation in mammary explants of CLA-induced MFD cows. The ratio of lipogenesis to oxidation, which reflects efficiency of lipogenesis (units of carbon incorporated into lipids per unit of carbon oxidized), was higher in AC than in CLA, but was not different from CON. The explant system is a challenging technique due to its limitations in terms of obtaining a representative biopsy sample and homogeneous tissue slices for incubation. In addition, it is known that subcutaneous adipose tissue is not as metabolically active as other depots, but challenges exist in obtaining mesenteric or visceral adipose tissue for this type of experiment. Due to the use of cannulated cows it was difficult to standardize stage of lactation in the current experiment (DIM $244 \pm 107$ ) and differences in physiological states and limitations of the explant system technique are expected to have contributed to the high standard error in the oxidation measurements and may have limited our ability to observe the expected response in adipose tissue (Figure 1).

\section{Adipose Tissue Gene Expression}

Harvatine et al. (2009b) reported increased expression of lipogenic transcription factors and enzymes and leptin in adipose tissue during CLA-induced MFD. It is well established that trans-10,cis-12 CLA downregulates expression of important transcription factors and enzymes involved in lipid synthesis in mammary tissue (e.g., Baumgard et al., 2002b; Harvatine and Bauman, 2006). Adipose tissue expression of key lipogenic factors and enzymes were observed in the current experiment and, contrary to Harvatine et al. (2009b), we observed few effects of CLA. Specifically, CLA had no effect on expression of the $S R E B P 1 c, S 14$, and $P P A R \gamma 1$, which are key regulators of lipogenic enzyme expression (Figure 2). Also, expression of ACCQ, FASN, and leptin were not affected by CLA; however, expression of fatty acid binding protein 4 (FABP4), perilipin 1 (PLIN1), and hormone-sensitive lipase $(H S L)$ were reduced in CLA compared with CON $(P<0.05)$. In accordance to our data, Saremi et al. (2014) did not see any changes in subcutaneous leptin expression during long-term CLA supplementation. Perilipin is a lipid-droplet coating protein that prevents basal lipolysis in the dephosphorylated state by protecting stored triglycerides from intracellular lipases, whereas HSL is an enzyme that upon phosphorylation initiates a lipolytic cascade of triglycerides stored in lipid droplets. Both, PLIN1 and HSL coordinately allow hormone-mediated lipolysis take place through activation of protein kinase $\mathrm{A}$ that is activated by extracellular hormonal signals that stimulate adenylyl cyclase (Sztalryd et al., 2003; Murray and Kincaid, 2012). In the dairy cow, the balance between adipose lipolysis and lipogenesis is key to support lactation, and is regulated by many factors including stage of lactation, energy intake, production level, and genetic merit (reviewed by McNamara, 2015). Increased lipolysis is one of the proposed mechanisms of reduced body fatness in CLA-treated animals (Park and Pariza, 2007), and the intracellular mechanism may involve decreased expression of PLIN1, allowing increased basal lipolysis to occur (Chung et al., 2005), which is in agreement with our data, as CLA decreased PLIN1 expression while increasing plasma NEFA. In accordance to our data, CLA treatment has previously been shown to decrease expression and translation of HSL in human abdominal adipose tissue cultures (Chung et al., 2005), although this decrease was accompanied with increased lipolysis, and therefore, a HSL-independent mechanism of CLA-lipolysis was suggested.

Acetate infusion did not affect expression of lipogenic regulators or enzymes, although we observed a numerical increase in leptin expression, and a reduction in expression of PLIN1 and HSL $(P<0.05$, Figure 2). It is possible that as mentioned above, the wide range of DIM of cows used limited our ability to observe a standard response of adipose lipogenic gene expression to CLA and acetate, and as suggested by de Veth et al. (2006), milk yield responses to CLA may depend on energy balance and level of production. As a consequence, it is expected that adipose lipogenesis and therefore changes in gene expression would depend on the fate of energy spared from milk fat synthesis. However, genes related to lipolysis were decreased with acetate infusion, without further indication of increased lipolysis, as plasma NEFA were unaltered. Interestingly, and as previously discussed, acetate infusions increased plasma BHB. Plasma BHB interacts with another G-protein receptor, GPR109A, which is an important 

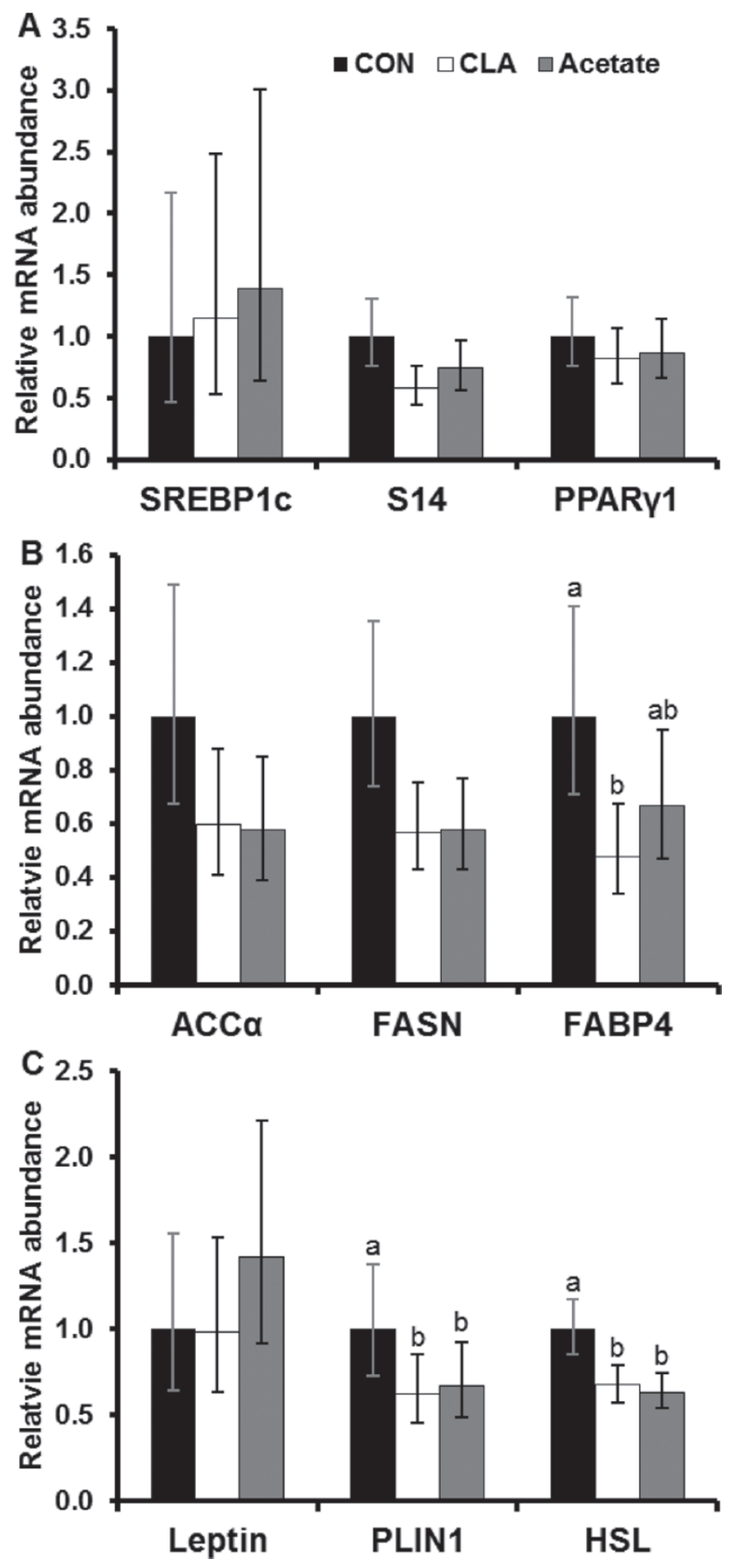

Figure 2. Effect of CLA and acetate on gene expression of mRNA of key lipogenic transcription regulators and enzymes in adipose tissue. Treatments were control (CON), 4-d abomasal infusion of $10 \mathrm{~g} / \mathrm{d}$ of trans-10, cis-12 CLA and cis-9,trans-11 CLA (CLA), and 4-d rumen infusion of $7 \mathrm{~mol} / \mathrm{d}$ of acetate adjusted to $\mathrm{pH} 6.1$ with sodium hydroxide (acetate); $\mathrm{n}=9$ per treatment. (A) Lipogenic factors, (B) key regulators of lipogenesis, and (C) energy balance and lipolysis genes. Values are LSM \pm SE of logarithmic back-transformed data expressed relative to control. Means that do not share a letter $(\mathrm{a}, \mathrm{b})$ are significantly different $(P<0.05)$. Acetyl-CoA carboxylase $\alpha(A C C \alpha)$, fatty acid binding protein $4(F A B P 4)$, fatty acid synthase $(F A S N)$, hormonesensitive lipase $(H S L)$, perilipin 1 ( $P L I N 1)$, peroxisome proliferator-activated receptor $\gamma(P P A R \gamma)$, sterol regulatory element binding protein 1 (SREBP1), and thyroid hormone responsive spot 14 (S14). metabolic sensor that has been shown to suppress lipolysis in adipose tissue during starvation (Ahmed et al., 2009). In the cow, GPR109A is abundantly expressed in adipose tissue where its expression was reduced as lactation progressed (Ahmed et al., 2009; Lemor et al., 2009; Friedrichs et al., 2014). It is likely that increased plasma BHB in the acetate treatment activated adipose GPR109A, suppressing lipolysis; however, it is unknown if a transduction mechanism that would involve decreased expression of lipolysis genes (e.g., PLIN1 and $H S L)$ is involved.

Short-chain FA, including acetate, have been reported to stimulate leptin release through activation of GPR; however, other reports show that acetate reduces plasma leptin due to an reduction in adipose tissue mass (reviewed by den Besten et al., 2013). In Harvatine et al. (2009b), energy spared from milk fat synthesis was likely partitioned to adipose tissue, in contrast to the reduced lipogenesis observed in the current study. Also, Choi et al. (2014) observed reduced lipogenesis capacity in adipose explants treated with trans-10,cis-12 CLA for $48 \mathrm{~h}$, but failed to see changes in gene expression of lipogenic enzymes. It is possible that trans-10, cis-12 CLA may exert some of its anti-lipogenic properties through changes other than gene expression (reviewed by Harvatine et al., 2009a; Bauman et al., 2011).

The effect of acetate on lipogenesis was studied in the 1970s and increasing acetate supply increased the rate of lipogenesis in bovine lipogenic tissue (Bauman et al., 1970, 1973). Also, in a mammary cell culture (MAC-T cells) acetate increased expression of $A C C \alpha$, one of the rate-limiting enzymes for de novo lipogenesis (Jacobs et al., 2013). However, in the current experiment, acetate had no effect on expression of lipogenic genes in adipose tissue, which is in agreement with no change in adipose lipogenesis capacity discussed above. Spared acetate may interact with the local microenvironment, resulting from hormone signaling inherent to physiological state, energy status, and level of production (McNamara and Hillers, 1986), and may or may not result in improved adipose lipogenesis, and therefore, energy balance (Orskov et al., 1969; Sheperd and Combs, 1998). As reviewed by Vernon (2005), in contrast to the mammary gland, adipose tissue lipogenesis is subject to different levels of chronic and homeorhetic control (auto-, para-, and endocrine), where the interaction of these factors play an important role in determining the lipolytic and lipogenic state of adipose tissue. In the current experiment, it is likely that spared energy provided by acetate was partitioned toward milk and milk fat synthesis, leaving little energy available for adipose tissue lipogenesis. Additionally, glucose and preformed FA spared during diet-induced MFD may have addi- 
tional effects that were not accounted for in the acetate treatment.

\section{CONCLUSIONS}

In conclusion, our data do not support the hypothesis that spared acetate increases adipose lipogenesis during CLA-induced MFD. In some situations, adipose tissue is sensitive to the anti-lipogenic effects of CLA, although the mechanism is not clear and may involve changes in protein translation or enzyme activity. Also, it appears that CLA may also affect insulin sensitivity in some situations as indicated by changes in plasma NEFA, BHB, and insulin, but this needs to be further investigated. Spared acetate does not appear to have a direct role in stimulating adipose lipogenesis; however, it may play an important role in stimulating mammary lipogenesis under conditions of normal milk fat (low alternate BH intermediates). The increase in milk fat may explain why adipose tissue lipogenesis was not increased. The effect of acetate supply on milk fat synthesis in the modern cow needs to be determined in future experiments. Finally, our data suggest that nutrient partitioning during CLA-induced MFD may depend on lactation stage, milk yield, and physiological state.

\section{ACKNOWLEDGMENTS}

The authors thank Felipe Pino for his assistance in performing adipose tissue biopsies, and Jackie Ying and Michel Baldin for their technical assistance during experimental periods (Penn State University, University Park). In addition, we thank Dale Bauman (Cornell University, Ithaca, NY) and Arnulf Troescher (BASF, Lampertheim, Germany) for helpful discussion, and BASF for the CLA stock and partial financial support of the study.

\section{REFERENCES}

ABI Prism. 2001. Relative quantification of gene expression. ABI Prism 7700 Sequence Detection System User Bulletin 2. Applied Biosystems, Foster City, CA.

Ahmed, K., S. Tunaru, and S. Offermanns. 2009. GPR109A, GPR109B and GPR81, a family of hydroxy-carboxylic acid receptors. Trends Pharmacol. Sci. 30:557-562.

AOAC International. 2000. Official Methods of Analysis. 17th ed. AOAC Int., Arlington, VA.

Baldwin, R. 1995. Modeling Ruminant Digestion and Metabolism. Springer Science \& Business Media.

Ballou, M. A., R. C. Gomes, S. O. Juchem, and E. J. DePeters. 2009. Effects of dietary supplemental fish oil during the peripartum period on blood metabolites and hepatic fatty acid compositions and total triacylglycerol concentrations of multiparous Holstein cows. J. Dairy Sci. 92:657-669.
Bartley, J. C., and A. L. Black. 1966. Effect of exogenous glucose on glucose metabolism in dairy cows. J. Nutr. 89:317-328.

Bauman, D., R. Brown, and C. Davis. 1970. Pathways of fatty acid synthesis and reducing equivalent generation in mammary gland of rat, sow, and cow. Arch. Biochem. Biophys. 140:237-244.

Bauman, D. E., and W. B. Currie. 1980. Partitioning of nutrients during pregnancy and lactation: A review of mechanisms involving homeostasis and homeorhesis. J. Dairy Sci. 63:1514-1529.

Bauman, D. E., and J. M. Griinari. 2001. Regulation and nutritional manipulation of milk fat: Low-fat milk syndrome. Livest. Prod. Sci. 70:15-29.

Bauman, D. E., K. J. Harvatine, and A. L. Lock. 2011. Nutrigenomics, rumen-derived bioactive fatty acids, and the regulation of milk fat synthesis. Annu. Rev. Nutr. 31:299-319.

Bauman, D. E., D. L. Ingle, R. W. Mellenberger, and C. L. Davis. 1973. Factors affecting in vitro lipogenesis by bovine mammary tissue slices. J. Dairy Sci. 56:1520-1525.

Baumgard, L. H., B. A. Corl, D. A. Dwyer, and D. E. Bauman. 2002a. Effects of conjugated linoleic acids (CLA) on tissue response to homeostatic signals and plasma variables associated with lipid metabolism in lactating dairy cows. J. Anim. Sci. 80:1285-1293.

Baumgard, L. H., B. A. Corl, D. A. Dwyer, A. Saebo, and D. E. Bauman. 2000. Identification of the conjugated linoleic acid isomer that inhibits milk fat synthesis. Am. J. Physiol. Regul. Integr. Comp. Physiol. 278:R179-R184.

Baumgard, L. H., E. Matitashvili, B. A. Corl, D. A. Dwyer, and D. E. Bauman. 2002b. Trans-10, cis-12 conjugated linoleic acid decreases lipogenic rates and expression of genes involved in milk lipid synthesis in dairy cows. J. Dairy Sci. 85:2155-2163.

Baumgard, L. H., J. K. Sangster, and D. E. Bauman. 2001. milk fat synthesis in dairy cows is progressively reduced by increasing supplemental amounts of trans-10, cis-12 conjugated linoleic acid (CLA). J. Nutr. 131:1764-1769.

Bell, A. W., and D. E. Bauman. 1994. Animal models for the study of adipose regulation in pregnancy and lactation. Pages 71-84 in Nutrient Regulation during Pregnancy, Lactation, and Infant Growth. Springer, New York, NY.

Bernal-Santos, G., J. W. Perfield Ii, D. M. Barbano, D. E. Bauman, and T. R. Overton. 2003. Production responses of dairy cows to dietary supplementation with conjugated linoleic acid (CLA) during the transition period and early lactation. J. Dairy Sci. 86:32183228 .

Bradford, B. J., and M. S. Allen. 2005. Phlorizin administration increases hepatic gluconeogenic enzyme mRNA abundance but not feed intake in late-lactation dairy cows. J. Nutr. 135:2206-2211.

Choi, S. H., D. T. Silvey, B. J. Johnson, M. E. Doumit, K. Y. Chung, J. E. Sawyer, G. W. Go, and S. B. Smith. 2014. Conjugated linoleic acid $(t-10, c-12)$ reduces fatty acid synthesis de novo, but not expression of genes for lipid metabolism in bovine adipose tissue ex vivo. Lipids 49:15-24.

Chung, S., J. M. Brown, M. B. Sandberg, and M. McIntosh. 2005. Trans-10,cis-12 CLA increases adipocyte lipolysis and alters lipid droplet-associated proteins: Role of mTOR and ERK signaling. J. Lipid Res. 46:885-895.

Covington, D. K., C. A. Briscoe, A. J. Brown, and C. K. Jayawickreme. 2006. The G-protein-coupled receptor 40 family (GPR40GPR43) and its role in nutrient sensing. Biochem. Soc. Trans. 34:770-773.

de Veth, M. J., E. Castaneda-Gutierrez, D. Dwyer, A. Pfeiffer, D. Putnam, and D. Bauman. 2006. Response to conjugated linoleic acid in dairy cows differing in energy and protein status. J. Dairy Sci. 89:4620-4631.

de Veth, M. J., J. M. Griinari, A.-M. Pfeiffer, and D. E. Bauman. 2004. Effect of CLA on milk fat synthesis in dairy cows: Comparison of inhibition by methyl esters and free fatty acids, and relationships among studies. Lipids 39:365-372.

den Besten, G., A. Bleeker, A. Gerding, K. van Eunen, R. Havinga, T. H. van Dijk, M. H. Oosterveer, J. W. Jonker, A. K. Groen, D. J. Reijngoud, and B. M. Bakker. 2015. Short-chain fatty acids protect against high fat diet induced obesity via a PPAR gam- 
ma dependent switch from lipogenesis to fat oxidation. Diabetes 64:2398-2408.

den Besten, G., K. van Eunen, A. K. Groen, K. Venema, D. J. Reijngoud, and B. M. Bakker. 2013. The role of short-chain fatty acids in the interplay between diet, gut microbiota, and host energy metabolism. J. Lipid Res. 54:2325-2340.

Donnelly, C., A. M. Olsen, L. D. Lewis, B. L. Eisenberg, A. Eastman, and W. B. Kinlaw. 2009. Conjugated linoleic acid (CLA) inhibits expression of the Spot 14 (THRSP) and fatty acid synthase genes and impairs the growth of human breast cancer and liposarcoma cells. Nutr. Cancer 61:114-122.

Foote, M. R., S. L. Giesy, G. Bernal-Santos, D. E. Bauman, and Y. R. Boisclair. 2010. t10,c12-CLA decreases adiposity in peripubertal mice without dose-related detrimental effects on mammary development, inflammation status, and metabolism. Am. J. Physiol. Regul. Integr. Comp. Physiol. 299:R1521-R1528.

Friedrichs, P., B. Saremi, S. Winand, J. Rehage, S. Danicke, H. Sauerwein, and M. Mielenz. 2014. Energy and metabolic sensing G protein-coupled receptors during lactation-induced changes in energy balance. Domest. Anim. Endocrinol. 48:33-41.

Fushimi, T., K. Suruga, Y. Oshima, M. Fukiharu, Y. Tsukamoto, and T. Goda. 2006. Dietary acetic acid reduces serum cholesterol and triacylglycerols in rats fed a cholesterol-rich diet. Br. J. Nutr. 95:916-924.

Harvatine, K. J., and D. E. Bauman. 2006. SREBP1 and thyroid hormone responsive spot 14 (S14) are involved in the regulation of bovine mammary lipid synthesis during diet-induced milk fat depression and treatment with CLA. J. Nutr. 136:2468-2474.

Harvatine, K. J., and D. E. Bauman. 2011. Characterization of the acute lactational response to trans-10, cis-12 conjugated linoleic acid. J. Dairy Sci. 94:6047-6056.

Harvatine, K. J., Y. R. Boisclair, and D. E. Bauman. 2009a. Recent advances in the regulation of milk fat synthesis. Animal 3:40-54.

Harvatine, K. J., J. W. Perfield 2nd, and D. E. Bauman. 2009b. Expression of enzymes and key regulators of lipid synthesis is upregulated in adipose tissue during CLA-induced milk fat depression in dairy cows. J. Nutr. 139:849-854.

Harvatine, K. J., M. M. Robblee, S. R. Thorn, Y. R. Boisclair, and D. E. Bauman. 2014. Trans-10, cis-12 CLA dose-dependently inhibits milk fat synthesis without disruption of lactation in C57BL/6J mice. J. Nutr. 144:1928-1934.

Ingle, D. L., D. E. Bauman, R. W. Mellenberger, and D. E. Johnson. 1973. Lipogenesis in the ruminant: Effect of fasting and refeeding on fatty acid synthesis and enzymatic activity of sheep adipose tissue. J. Nutr. 103:1479-1488.

Itoh, Y., Y. Kawamata, M. Harada, M. Kobayashi, R. Fujii, S. Fukusumi, K. Ogi, M. Hosoya, Y. Tanaka, and H. Uejima. 2003. Free fatty acids regulate insulin secretion from pancreatic $\beta$ cells through GPR40. Nature 422:173-176.

Jacobs, A., J. Dijkstra, J. Liesman, M. VandeHaar, A. Lock, A. van Vuuren, W. Hendriks, and J. van Baal. 2013. Effects of short-and long-chain fatty acids on the expression of stearoyl-CoA desaturase and other lipogenic genes in bovine mammary epithelial cells. Animal 7:1508-1516.

Kadegowda, A. K. G., T. A. Burns, S. L. Pratt, and S. K. Duckett. 2013. Inhibition of stearoyl-CoA desaturase 1 reduces lipogenesis in primary bovine adipocytes. Lipids 48:967-976.

Karkalas, J. 1985. An improved enzymic method for the determination of native and modified starch. J. Sci. Food Agric. 36:1019-1027.

Kondo, T., M. Kishi, T. Fushimi, S. Ugajin, and T. Kaga. 2009. Vinegar intake reduces body weight, body fat mass, and serum triglyceride levels in obese Japanese subjects. Biosci. Biotechnol. Biochem. 73:1837-1843.

Kramer, J. K., V. Fellner, M. E. Dugan, F. D. Sauer, M. M. Mossoba, and M. P. Yurawecz. 1997. Evaluating acid and base catalysts in the methylation of milk and rumen fatty acids with special emphasis on conjugated dienes and total trans fatty acids. Lipids $32: 1219-1228$.

Leighton, B., A. R. Nicholas, and C. I. Pogson. 1983. The pathway of ketogenesis in rumen epithelium of the sheep. Biochem. J. 216:769-772.
Lemor, A., A. Hosseini, H. Sauerwein, and M. Mielenz. 2009. Transition period-related changes in the abundance of the mRNAs of adiponectin and its receptors, of visfatin, and of fatty acid binding receptors in adipose tissue of high-yielding dairy cows. Domest. Anim. Endocrinol. 37:37-44.

Lemosquet, S., S. Rigout, A. Bach, H. Rulquin, and J. Blum. 2004. Glucose metabolism in lactating cows in response to isoenergetic infusions of propionic acid or duodenal glucose. J. Dairy Sci. $87: 1767-1777$

Litherland, N., S. Thire, A. Beaulieu, C. Reynolds, J. Benson, and J. Drackley. 2005. Dry matter intake is decreased more by abomasal infusion of unsaturated free fatty acids than by unsaturated triglycerides. J. Dairy Sci. 88:632-643.

Maxin, G., F. Glasser, C. Hurtaud, J. L. Peyraud, and H. Rulquin. 2011a. Combined effects of trans-10, cis-12 conjugated linoleic acid, propionate, and acetate on milk fat yield and composition in dairy cows. J. Dairy Sci. 94:2051-2059.

Maxin, G., H. Rulquin, and F. Glasser. 2011b. Response of milk fat concentration and yield to nutrient supply in dairy cows. Animal 5:1299-1310.

McNamara, J. P. 2015. TRIENNIAL LACTATION SYMPOSIUM: Systems biology of regulatory mechanisms of nutrient metabolism in lactation. J. Anim. Sci. 93:5575-5585.

McNamara, J. P., and J. K. Hillers. 1986. Regulation of bovine adipose tissue metabolism during lactation. 1. Lipid synthesis in response to increased milk production and decreased energy intake. J. Dairy Sci. 69:3032-3041.

Murray, R. K., and R. Kincaid. 2012. Harper's Illustrated Biochemistry. McGraw-Hill Medical.

Odens, L. J., R. Burgos, M. Innocenti, M. J. VanBaale, and L. H. Baumgard. 2007. Effects of Varying Doses of Supplemental Conjugated Linoleic Acid on Production and Energetic Variables During the Transition Period. J. Dairy Sci. 90:293-305.

Orskov, E. R., W. P. Flatt, P. W. Moe, and A. W. Munson. 1969. The influence of ruminal infusion of volatile fatty acids on milk yield and composition and on energy utilization by lactating cows. Br. J. Nutr. 23:443-453.

Ostrowska, E., R. F. Cross, M. Muralitharan, D. E. Bauman, and F. R. Dunshea. 2002. Effects of dietary fat and conjugated linoleic acid on plasma metabolite concentrations and metabolic responses to homeostatic signals in pigs. Br. J. Nutr. 88:625-634.

Ostrowska, E., M. Muralitharan, R. F. Cross, D. E. Bauman, and F. R. Dunshea. 1999. Dietary conjugated linoleic acids increase lean tissue and decrease fat deposition in growing pigs. J. Nutr. 129:2037-2042.

Pappritz, J., U. Meyer, R. Kramer, E.-M. Weber, G. Jahreis, J. Rehage, G. Flachowsky, and S. Danicke. 2011. Effects of long-term supplementation of dairy cow diets with rumen-protected conjugated linoleic acids (CLA) on performance, metabolic parameters and fatty acid profile in milk fat. Arch. Anim. Nutr. 65:89-107.

Park, Y., and M. W. Pariza. 2007. Mechanisms of body fat modulation by conjugated linoleic acid (CLA). Food Res. Int. 40:311-323.

Perfield, J., G. Bernal-Santos, T. Overton, and D. Bauman. 2002. Effects of dietary supplementation of rumen-protected conjugated linoleic acid in dairy cows during established lactation. J. Dairy Sci. 85:2609-2617.

Raabo, E., and T. Terkildsen. 1960. On the enzymatic determination of blood glucose. Scand. J. Clin. Lab. Invest. 12:402-407.

Rico, D. E., and K. J. Harvatine. 2013. Induction of and recovery from milk fat depression occurs progressively in dairy cows switched between diets that differ in fiber and oil concentration. J. Dairy Sci.96:6621-6630.

Saremi, B., S. Winand, P. Friedrichs, A. Kinoshita, J. Rehage, S. Danicke, S. Haussler, G. Breves, M. Mielenz, and H. Sauerwein. 2014. Longitudinal profiling of the tissue-specific expression of genes related with insulin sensitivity in dairy cows during lactation focusing on different fat depots. PLoS One 9:e86211.

Schmidt, J., K. Liebscher, N. Merten, M. Grundmann, M. Mielenz, H. Sauerwein, E. Christiansen, M. E. Due-Hansen, T. Ulven, and S. Ullrich. 2011. Conjugated linoleic acids mediate insulin release 
through islet G protein-coupled receptor FFA1/GPR40. J. Biol. Chem. 286:11890-11894.

Sheperd, A., and D. Combs. 1998. Long-term effects of acetate and propionate on voluntary feed intake by midlactation cows. J. Dairy Sci. 81:2240-2250.

Smith, S. B. 1983. Contribution of the pentose cycle to lipogenesis in bovine adipose tissue. Arch. Biochem. Biophys. 221:46-56.

Spires, H., J. Clark, R. Derrig, and C. Davis. 1975. Milk production and nitrogen utilization in response to postruminal infusion of sodium caseinate in lactating cows. J. Nutr. 105:1111-1121.

Storry, J., and J. Rook. 1965a. Effect in the cow of intraruminal infusions of volatile fatty acids and of lactic acid on the secretion of the component fatty acids of the milk fat and on the composition of blood. Biochem. J. 96:210-217.

Storry, J., and J. Rook. 1965b. Effects of intravenous infusions of acetate, $\beta$-hydroxybutyrate, triglyceride and other metabolites on the composition of the milk fat and blood in cows. Biochem. J. 97:879.
Sutton, J. D., M. Dhanoa, S. Morant, J. France, D. Napper, and E. Schuller. 2003. Rates of production of acetate, propionate, and butyrate in the rumen of lactating dairy cows given normal and low-roughage diets. J. Dairy Sci. 86:3620-3633.

Sztalryd, C., G. Xu, H. Dorward, J. T. Tansey, J. A. Contreras, A. R. Kimmel, and C. Londos. 2003. Perilipin A is essential for the translocation of hormone-sensitive lipase during lipolytic activation. J. Cell Biol. 161:1093-1103.

Terpstra, A. H. 2004. Effect of conjugated linoleic acid on body composition and plasma lipids in humans: An overview of the literature. Am. J. Clin. Nutr. 79:352-361.

Van Soest, P. J., J. B. Robertson, and B. A. Lewis. 1991. Methods for dietary fiber, neutral detergent fiber, and nonstarch polysaccharides in relation to animal nutrition. J. Dairy Sci. 74:3583-3597.

Vernon, R. G. 2005. Lipid metabolism during lactation: A review of adipose tissue-liver interactions and the development of fatty liver. J. Dairy Res. 72:460-469. 